\title{
Misunderstanding Raymond: Cultural Technology and Knowledge Transfers in Transnational Scripted Format Production
}

\author{
Jeffrey Brassard ${ }^{1}$ \\ UNIVERSITY OF ALBERTA \\ jrb5 [AT] ualberta.ca
}

\begin{abstract}
In 2010, Philip Rosenthal, the showrunner of the long-running sitcom Everybody Loves Raymond, released a documentary titled Exporting Raymond that focused on his experience helping Sony Television International adapt the series in Russia. The documentary provides a rare behind-the-scenes examination of the process of taking a scripted format from one national context to another, and several recent accounts of the film have sought to use it as a way of understanding the way American studios approach international television markets. Using the documentary, industry trade publications, and interviews with people working in the Russian television industry, this article argues that rather than seeing Exporting Raymond as an example of cultural imperialism, it should be seen as an example of the way Western studios strengthen emerging industries by developing human capital and importing production and writing techniques that improve local programming.
\end{abstract}

Keywords: Russian Television, Media Industries, Global Television, Scripted Formats, Cultural Translation

In 2010, Philip Rosenthal, the showrunner of the long-running sitcom Everybody Loves Raymond (1996-2005), released a documentary titled Exporting Raymond (2010) that focused on his experience helping Sony Television International adapt the series in Russia. Although the documentary provides a rare behind-the-scenes examination of the process of transferring a scripted format from one national context to another, it has received relatively little critical attention. Recent accounts of the film by Aniko Imre, in her broader work on television in socialist and post-socialist states, and Julia Petuhova, who commented on the 
documentary, have sought to use it as a way of understanding the general attitude that American studios adopted toward international markets in the 2000s. These accounts frequently paint the Hollywood studios as boorish conquistadors, blithely entering cultures they do not care to understand and imposing their norms and expectations of drama and comedy on other cultures. While this account might ultimately make sense of some cultural exchange around the world, it is an incorrect assessment of Exporting Raymond. Rosenthal's documentary, in fact, depicts a small part of a much larger project of cultural technology transfer from the West to Russia that took place in the television industry in the 2000s and 2010s. While Imre, Petuhova, and several other popular-level discussions of the documentary principally frame the creation of the Russian version of Everybody Loves Raymond with notions of cultural imperialism, this article undertakes a wider examination of the documentary within the broader framework of the transformations taking place in the Russian television industry in the 2000s. Consequently, it suggests that while elements of cultural imperialism are present, the story of Exporting Raymond also foregrounds considerable Russian resistance to the American process, and eventually a broad appropriation and transformation of the Everybody Loves Raymond format into a hybridized Russian version of itself. This process is achieved principally by the transfer of cultural technologies from Hollywood to Moscow. The ultimate result of this is the creation of a powerful Russian sitcom industry that now seems poised to enter the global marketplace.

This article uses interviews gathered as part of a larger research project on the Russian media industry. In total, ten interviews were conducted with American and British consultants who were working, or had previously worked, in the Russian television industry and with Russian media personnel. Of the ten interviews, seven were with British or American consultants and three were with Russian media industry personnel. Three of the people interviewed, including two of the Russians, were on the set of the adaptation of Everybody Loves Raymond as Rosenthal was consulting. Consequently, they have first-hand knowledge of the events of the documentary. Since all of them asked not to be identified, they spoke openly about their role in creating the series and about the struggles that occurred between the Russian producers and American consultants. It is remarkable that given that they were often on opposite sides of the debates in the documentary, by 2014, when they were interviewed they all gave remarkably similar assessments of what ultimately made the Russian version of Everybody Loves Raymond successful.

One of the most prominent academic accounts of Rosenthal's documentary comes from Aniko Imre's treatment of television in socialist countries. Imre, like most other scholars in the West, essentially takes it for granted that Rosenthal is a cultural rube for not understanding that humor is culturally embedded or that comedy does not travel well. The American showrunner comes to Russia with the perspective that the humor at the core of Everybody Loves Raymond, discontinuity, and conflicts that occur within families should be equally appealing to Russian audiences. The humor in Everybody Loves Raymond comes principally from the frequent conflicts between Deborah (Patricia Heaton) and Raymond (Ray Romano). Typically, these are driven by Raymond's somewhat obtuse nature, a general obsession with sports, and lack of interest in contributing to his family's domestic life. The other source of conflict in the American original is the proximity and continual presence of Raymond's parents and adult brother in the Romano home. The in-laws live across the street, 
come over unannounced, and Raymond's mother, Marie (Doris Roberts), is overly critical of Deborah's housekeeping and parenting skills. Rosenthal sees these conflicts as essentially universal to families everywhere, assuming that under the surface of every marriage, there is conflict between spouses and other family members that, when viewed from the outside, might be a source of humor. He assumes that since families exist everywhere, humor arising from people living together in such close quarters must also exist.

It is this assumption of the universalism of family conflict that essentially drives the conflict between Rosenthal and the Russians. Rosenthal struggles at moments, trying to explain why these incongruities are funny and why, ultimately, they should move easily across cultural boundaries. During one scene after a particularly testy exchange with the Russian writers, Rosenthal admits that "I thought it was universal, I thought it was. Maybe not." It is fundamentally here that Rosenthal is critiqued by scholars in the West looking at his work on translating Everybody Loves Raymond to the Russian context. Imre puts the problem as follows: "the more important issue for my purposes here is the ethnocentric assumptions towards Russia ... in Rosenthal's attitude toward comedy," continuing that

we can safely assume the reason, it was so hard to translate its humor was not that Russian audiences had no comic sophistication and were desensitized to humor in everyday life. The assumption that they had never before experienced the comic in the "absurdity of everyday interactions" is absurd in itself.

She continues by suggesting, "If they could have a voice, I speculate that they would say their resistance to [Everybody Loves] Raymond is not because the show's humor is too sophisticated and absurd but, conversely, because it is too mundane and shallow." Rosenthal and the Americans in the film are certainly at their worst when they appear to be talking down to the Russian producers of the series. As the star of the film, Rosenthal is particularly guilty of appearing paternalistic because the audience hears his thoughts directly and in voiceover. Imre takes particular issue with a statement from Rosenthal in an interview about the film, wherein he is asked whether Russians have anything to teach their American counterparts about making television, and he somewhat curtly replies that "No. They don't have the experience, the resources that we have. It's like a child trying to teach the adult." She seems to take this to mean that the Russians have no grasp of television humor in general. She attempts to refute this perception by listing some exemplars of the rich history of Russian satire and humor.

Imre's objections to the way that the film portrays Russians are typical of those of other critics and scholars. As David Edelstein writes in New York Magazine, "[Rosenthal] doesn't consider the possibility that the flamboyantly fashionable costume designer might have insights into Russian housewives . . he spends most of his time searching for similarities instead of differences." ${ }^{3}$ Scott Tobias writing for NPR notes that "For all his talk of creating 'a very specific family', grounded in reality, Rosenthal is so convinced of his show's universal appeal that he can't comprehend why it might have to be tweaked for another culture." ${ }^{4}$ As Julia Petuhova notes, "[the documentary] becomes increasingly unable to corroborate his frustrations, and the viewer begins to feel that Rosenthal's inability to accept the Russian producers' agency to revise the source material is irrational." She adds that "an intertitle divulges that the 
Russian show was not only highly successful but also became the highest-rated Russian sitcom." ${ }^{6}$ From this fact, she deduces that Rosenthal's interventions were simply a matter of his lack of comprehension of the nuances of adapting his beloved sitcom to the Russian market. She suggests that had he left the Russians alone to do their work, they would have correctly identified the right target audience. In her estimation, the eventual success of the program is ultimately a result of the Russian producers' sophisticated ability to adapt Western programs to the Russian market. She also cites the ability of Russian stations to air reality television and game shows adapted from the West as evidence that Rosenthal underestimates the Russians.

There are, of course, multiple ways that different sets of academic literature might be used to understand the events depicted in the series. The literature on post-socialism, for example, is likely to understand adaptations of American programs on Russian television as a post-socialist hybrid incorporating the new neoliberal realities of post-Soviet Russian life with the aspects of socialism that continue to haunt the nation. As Katarzyna Marciniak notes, the products that emerge in the post-socialist systems mix "old, enduring socialist realities with the welcomed arrival of western goods, images and new models of desirable identities."7 Thus, the trouble faced by Rosenthal might be a result of the attempt to blend Everybody Loves Raymond into this haunted post-Soviet reality. Alternatively, proponents of the theories that consider consumptive practices of the audience might suggest that the ultimate problem faced by the producers of the series on both sides was one of cultural proximity. ${ }^{8}$ This perspective might note that much of the trouble in the documentary stems from the relative cultural distance between Russia and America, creating a disconnect, particularly with regard to humor. Other notable perspectives might observe, as Brett Mills does, that sitcoms come with a nationally specific set of production practices linked to their history and role in the US television industry. The particularities that arise from these factors might account for how difficult it was to translate that process to Russia. ${ }^{9}$

All these perspectives offer potential insight into the events that take place in Rosenthal's documentary. There is, however, more to the story of both the documentary and the history of Russian sitcoms in general that contradict most of the received wisdom about Russian sitcoms. Most of the critics misunderstand the history of Russian sitcoms specifically because they view them only from outside with no voices from the Russian television industry or even from Hollywood producers interjecting their lived experience of producers into the overarching narratives of global format adaptations. Accounts like those above perpetuate misconceptions about Russian sitcoms because the only evidence discussed is from the documentary. Consequently, Rosenthal's comment that the Russians had nothing to teach Westerners about comedy seems to be coming from a place of condescension. By contrast, when one understands the broader context of Russian television during the period in question, it becomes clear that Rosenthal's comment is more likely an accurate reflection of onthe-ground realities at the time he was in Russia. To put it simply, when Rosenthal was consulting on the project, the Russian television industry was in such an underdeveloped state that it required significant inputs of knowledge not only from Hollywood but also from Latin America to learn the craft of producing television programs. Once several cultural technologies had been transferred and hybridized by Russian media workers, they were able to stop relying so heavily on these outside sources of experience and even began producing media aimed at the global television marketplace. 
The lack of experience producing television in a competitive market was evident in the 2000s in Russia. The Soviet industry was, of course, not particularly competitive as the nature of that economy essentially allowed cultural elites to dictate what was going to be on television. High-quality fictional television existed, but it was relatively rare because, as Kristin Roth-Ey notes, the motion picture industry jealously controlled the supply of film stock and refused to share it with television producers whom they viewed as inferior. ${ }^{10}$ Most of the important series from the Soviet period were referred to as episodic films since they had between five and twelve episodes owing largely to the lack of access to film stock and production spaces.

While a few other series were produced during the Soviet period, they all follow a similar pattern to the ones outlined above. The first aspect to note is that Soviet television series appeared relatively late compared to their Western counterparts. By the late 1940s, American television networks were already producing programs like The Laytons (1948) and The Goldbergs (1949-1956), which had made the jump from radio where melodramas, police dramas, sitcoms, and many other genres were already well established. Consequently, the Soviet industry was decades behind its American counterpart from the beginning. While this gulf might well have been bridged eventually, the Soviet television industry remained underresourced until the collapse of the USSR in 1991. Because long-running series were absent, the skills required to write television series spanning hundreds of episodes that would be required once the television system in Russia switched to one that was advertiser-supported were never developed.

The initial switchover to a capitalist market did not go well for the Russian television industry. Like much of the rest of the Soviet economy, television was ill-prepared to compete in the global market. At the time of the collapse of the Soviet state, there were very few film or television studios in Russia. In total, the Soviet Union had approximately twenty-five film and animation studios. After the breakup of the USSR, the country was left with only five: Mosfilm, Gorky Film Studio, Lenfilm, Studio Ekran, and Sverdlovsk Film Studio. One of these, Studio Ekran, was closed in 1994 when the state-owned television broadcaster Ostankino reorganized. These spaces were, at the time, not equipped with the most state-of-the-art film equipment. As a result, when the time to produce their own television series came, Russians lacked both the physical spaces required, still had to compete with film productions for studio space, and had poor production values because of a lack of experience and poor facilities.

The result of these forces was that Russian series virtually disappeared in the 1990s save for some of the old Soviet series that were reformatted to fit a fifty-minute time slot. Consequently, for much of the 1990s, the Russian television industry continued to flounder. People once employed in the Soviet film industry moved on to other jobs more capable of sustaining them in the new economy. The situation changed suddenly in 1998. Russia was embroiled in the Asian financial crisis, which caused the collapse of the Russian economy and the devaluation of its currency. Television stations still needed to air content, but as Prokhorova notes,

In the early 1990s, Russian television channels had paid \$15 thousand for an episode of a Mexican soap opera (and considerably more for an American), which was to be broadcast twice. After the economic collapse, however, most channels were unable or unwilling to do so. As a result, studios increased the production of native series, which, after the initial investment, could be shown on different channels, syndicated, and released on videotape. ${ }^{11}$ 
What followed was a total reshaping and massive expansion of the Russian television industry. The first new Russian series to find genuine success in the Russian market were police dramas like Streets of Broken Lights (1998-2019), Criminal St. Petersburg (20002007), and Kamenskaya (1999-2012). When these series proved profitable, it triggered a race to produce new series. By the early 2000s, Russian television stations were building new production spaces in abandoned warehouses on the outskirts of Moscow. People who were able to work in television production became a valued commodity. This trend is apparent in a scene in Rosenthal's documentary, where he tries to forge a connection with the Russian screenwriters. They complain that they sleep only a few hours a night and that they quickly shift from project to project because their talents are so in demand. In fact, after the adaptation of Everybody Loves Raymond was put on hold, Rosenthal returns to Moscow to find that those writers are no longer attached to the project, having moved on to other series.

The aspect of the Russian television industry that is most important when it comes to an understanding of the sitcoms is the complete disarray that the industry found itself in following the Soviet collapse. The Soviet television industry was never particularly large or sophisticated, but following the end of communism, funding for the industry virtually disappeared, resulting in a loss of human capital. ${ }^{12}$ When Russians began to make television programs in significant numbers in the 2000s once again, there were not enough qualified writers, producers, and actors who understood comedy. Dana Heller documented the inability of Russian producers to make a successful sitcom in the 1990s. She notes that the first two Russian sitcoms Family Business, Funny Business (1997) and Strawberry Café (1997) failed to find a home in the Russian media market primarily because "the sitcoms were vapid and poorly written," an assessment with which critics generally agreed. She further notes that "Iurii Volodarski, recently hailed as the "courageous pioneer of the genre conventionally called Russian sitcom', attributes the problem to a general decay of Russian comedic ability, the result of the film and television industry's financial woes." She continues, noting that "For the last ten years there have been practically no comedies made, no actors to play in them and they forgot what they learned."13 Heller's examination of these two early sitcoms reveals the state of the industry that Rosenthal ultimately experienced ten years later, an industry with little experience in how to produce comedies either on film or on television.

The Russian television industry during this period was drastically short of people experienced in making television series. The underdevelopment of Soviet television and the nearly decade-long period where Russian studios produced little had not prepared the industry for the sudden boom in television production. As a result, the people working on television production like the one spearheaded by Rosenthal and Sony frequently had little experience with how to produce television in general and long-running series in particular. Simon Tucker, a former British television producer and part-owner of the fifth-largest television production company in Russia, notes that when he started producing television in Russia in the 2000s,

People [were] not generally very good at telling stories ... When I got to Russia, it was like "voiceover, no, we don't do any voiceover. We want to confuse the audience in that way, so they really have to 
think." I was like, "why? It's three o'clock in the afternoon; I'm not really watching the television. I'm either ironing or cooking something, and the television is on. So you have to tell them where they are."14

Tucker's impression of the state of the Russian industry was further attested to by an international format consultant who suggested that

The Russians want to believe they can do it all by themselves. They don't have the subtlety in their sensibility to look at pages and see [that] it can be better because of this, or it's not working because of that. They make the classic mistakes [that] every writer in a sitcom faces: "This joke is hilarious, but it's not really in character." The pro says, "Well, we can't use the joke." Those guys, they'll go for one joke, that'll kill the character. ${ }^{15}$

Russians did not know how to make sitcoms, and as a result, Family Business, Funny Business and Strawberry Café were dismissed as amateurish, particularly when compared to American sitcoms that had been airing with dubbing on Russian television in the years following the collapse of the USSR. Both series had been purchased as formats, and Russian producers had attempted to adapt them with little to no guidance from the owners of the formats. Since they lacked the institutional memory and knowledge about what makes these types of series popular, it is no surprise that they failed to adapt them in a way that was appealing to the Russian public until they received substantial assistance and cultural technology transfers from Western partners.

The first genuinely successful sitcom in Russia was the 2004 adaptation of the CBS series The Nanny (1993-1999). The series was wildly successful, to the point that the Russian network adapting the series requested that Sony provide it with scripts for an additional season worth of episodes. The further success of Who's the Boss (1984-1992) and Married with Children (19871997) might be taken to mean that by the late 2000s Russian producers had learned how to make sitcoms successfully. If one examines the history of Russian sitcoms in more depth, however, several facts become quite conspicuous. They show that the story of the development of sitcoms in Russia is much more complicated than typical accounts attest. Specifically, the comedies listed above as being successful tell only part of the story. These comedies were not the only ones brought to the Russian market. In fact, the success of The Nanny on Russian television started a stampede by American studios to try and take advantage of Russia's new fascination with the genre. This rush ultimately led to a near depletion of available sitcom formats by the beginning of the 2010s. ${ }^{16}$ Numerous programs outside of the ones typically listed were brought to Russia. Perhaps the most prominent of these were Home Improvement (1991-1999) and Golden Girls (1985-1992). The adaptation of Home Improvement called Papa na vse Ruki (2006) lasted only forty episodes or two seasons. While two seasons might not seem like an abject failure in Western terms, the pace of production and airing in Russia where series air four nights a week means the series was a failure. In reality, it aired only four months, from November 2006 to February 2007, before being canceled. The adaptation of Golden Girls called Bolshie Devochki (2006) did even more poorly and was canceled after thirty-two episodes. Many other series were pitched and sold to Russian channels, but they failed to find an audience.

On the surface, one might explain the successes and failures of individual programs to the vagaries of audience tastes. Perhaps the programs that failed simply did not appeal to the target market in Russia. In her examination of Exporting Raymond, Petuhova suggests that 
the largest target demographic is older women, while in America, it is the demographic of fourteen- to thirty-year-olds. As a result, series might have to be retooled for an older audience or at very least series that appeal to an older demographic might be selected. While one can understand why Home Improvement, a program which originally featured the hypermasculine Tim Allen, might not ultimately appeal to that demographic, Golden Girls surely should have. Such a reading of the Russian market also surely does not explain the success of Married with Children or Everybody Loves Raymond in the Russian market. Consequently, a better explanation of why certain series failed to find an audience in Russia while others succeeded is necessary.

The most plausible explanation for this discrepancy relates principally to which Western companies brought series to the Russian market and their overall tactics. Mark Lorber, an international format consultant who worked for Sony in Russia during the 2000s, though he left Russia and Sony prior the events of Exporting Raymond, states that

Some studios just sold them [programs] and had very little consultancy. Disney sent in someone for three weeks on Golden Girls; I was there during that time and talked to Disney afterward and told them that was the wrong thing to do. Warner [Brothers] never got their act together ... [There were] six comedies that they sold in that never made it to pilots. Another two got piloted and never made it to air, and a few never made it very long beyond that [sic]. ${ }^{17}$

What Lorber's comments allude to is that many of the series sold to Russian companies failed because the American companies that owned the rights to them misunderstood the Russian market. Clearly, they assumed that Russia had a functional television infrastructure that included personnel capable of writing and adapting scripts with very little oversight. As a result, they sent consultants into Russia for a few weeks to help with some of the basics of the design of the program, and then those consultants left to work on other projects. The assumption that Russians would essentially have a functional television industry is reasonable since most of the other markets that the Hollywood studios tried to enter in the 2000s had somewhat developed television infrastructure.

The adapted series that did succeed had a very simple common feature; all of them were brought to Russia by Sony. The reason for their success was that Sony, unlike its other rivals in the scripted fiction realm, was not content to merely sell the series to a Russian network and then walk away; the company invested heavily in the Russian market. When asked why Sony had had such success in the Russian market while other companies had failed, another international format consultant explained that

The answer is simple. Sony committed fully to trying to make this work, and what that means is putting boots on the ground for more than a week, you know. All the places you just mentioned have had shows come over, and they'll send an American over for a week or two weeks and then pull them. Sony commits and has committed from the very initial stage of writing through post-production. ${ }^{18}$

Sony's investment in the Russian television market was and remains substantial. It began around 2003 when the company began consulting on the Russian-made series Poor Anastasia (Bednaya Nastya) (2003-2004) and continues to the present. Consultants are the principal 
vector through which Sony has worked in the Russian market, and most industry insiders credit them with the success of Sony programs. When asked why Sony series had succeeded in the Russian market and others had not, a Russian creative director who had worked with the company stated,

It's very simple: consultants. I had to say it because now I'm going to sound like as usual on the other side of things, but American writers, American producers on the ground. Not just, "Oh, we're coming for two weeks," as most other people do. [with the attitude of] "Let's get it on track, and then Russians will take over because they've already learned, and they know how to do that." American consultants in the writing room, on stage. That's the secret. That's the secret of Married [with Children]... That's the secret of Nanny. That's the difference. That's something which makes this difference, why Sony is successful, and others are not as successful [sic]. ${ }^{19}$

The importance of the consultants is also evident from the documentary itself. The principal point of contact between the Russians and Rosenthal is a man named Richard Vaczy. His LinkedIn page lists Vaczy as an international format consultant. An examination of his IMDb page shows that he is a veteran Hollywood writer having written scripts for the American version of both Married with Children and Golden Girls. Vaczy is credited as an executive producer on several Russian programs, including the adaptation of The Nanny, Married with Children, and Everybody Loves Raymond. His first credit on a Russian program is in the second season of the adaptation of The Nanny in 2005, and his last is in 2013, meaning that he was in Russia consistently for at least eight years. Consequently, Vaczy was deeply involved in the production of programs in Russia long before Rosenthal arrived and long after Rosenthal left. Given the lack of television infrastructure and human capital in Russia during this period, the success of the Russian version of Everybody Loves Raymond can broadly be attributed not to the inventiveness and sophistication of the Russians involved but rather to the American consultants and American companies that invested in the market.

The results of Sony's efforts to provide on-the-ground assistance in the production of the Russian versions of the programs were a wild success. A vice president of international development at a major US studio, who was familiar with Sony's work in Russia, revealed in an interview that Sony had used several strategies to deal with the success of adaptation that they brought to Russia. The Russian version of The Nanny added an extra season of content. The Russian network that commissioned the program, STS, requested additional episode scripts from Sony for adaptation. Sony brought together some of the original writers from the American series who then repurposed rejected episodes from the original series and created new episodes for the Russian production to use. ${ }^{20}$ When TNT, the network producing the Russian version of Married with Children, requested more material, Sony's consultants in Russia worked with the Russian production company to produce the new scripts. The Americans let the Russians take the lead on the production of the new scripts, totaling about one hundred new episodes, but remained in place to protect the brands of the programs involved and to steer the Russians away from common errors. This strategy was replicated with Everybody Loves Raymond. Vaczy and other consultants helped the Russian network and studios produce new scripts under their supervision. At present, the series has aired 466 episodes, 256 more than the Russian original, becoming the longest running adapted series in history. ${ }^{21}$ 
Given the success of the series and the available facts, the inevitable conclusion is that the taken-for-granted accounts of the series as mere evidence of American cultural imperialism and chauvinism are problematic. There are certainly aspects of cultural imperialism present in the case. Sony, coming from Hollywood, is certainly the dominant player in the relationship with the Russians. There is also a sense given in the documentary that the Russians need the guidance of the Americans. As presented in the documentary, Rosenthal's interventions are generally correct. The documentary and subsequent history of the program suggest that he correctly discerns that a series about mundane family interactions would, in fact, resonate with Russian audiences. He was also broadly depicted as correct with regard to several of the comedic choices that he comments on in the series. The last act of the documentary is particularly telling. In this portion of the film, the two leads struggled to successfully depict a fight over whether a bottle of orange juice had already been opened. Rosenthal seems to grasp what many of the Russians on-set do not, that the male actor Sergei Kuzkin's melodramatic acting during the scene makes his on-screen wife's behavior seem inappropriate. Rosenthal's general dislike of Kuzkin seems to be ultimately correct since the actor was replaced because prerelease focus groups also did not like him. Viewed through the lens of these facts, the prism of cultural imperialism seems to offer only a partial explanation of the events of the documentary and the development of the Russian version of Everybody Loves Raymond.

Given the broader history of the program, including the hundreds of additional episodes created with significant input from Russian writers, Exporting Raymond should be recast not simply as the struggle between the imperialistic Americans and the recalcitrant Russians but also as the transfer of cultural technologies from Hollywood to Moscow that has resulted in the creation of a domestic Russian television industry that remains Russian in character but has successfully appropriated Western genres and techniques for its own purposes. Michael Keane, Anthony Y.H. Fung, and Albert Moran propose that formats and other cultural texts are, in essence, types of cultural technologies. ${ }^{22}$ They define the term stating that "cultural technology has a more direct connotation to television content if linked to the idea of 'knowledges' about production, about marketing, and about consumer patterns ... all commercial entertainment media are cultural technologies insofar as they aim to attract your attention, keep your attention and-in the case of commercial television-sell your attention to advertisers," adding that

Cultural technology transfer has two edges. In a material sense, a cultural commodity is formed; in another sense, the success of the commodity ... leads to further dissemination of the technology ... cultural technology transfer entails looking at program flows through the pragmatic lens of content internationalization. ${ }^{23}$

They conclude that

The cultural technology transfer model is, therefore, a way of bridging the gap between modernization theory that supposes that modern "Western" technology and its ways of organization contribute to the inevitable transition from tradition to modernity, and media imperialism, which has tended to see foreign programming as a threat to social values. In effect, the equation is not so straightforward ... cultural technology transfer of format licensing and appropriation depends on the environment in which it is transplanted. Sometimes it takes, sometimes it doesn't. ${ }^{24}$ 
They also note that a very important aspect of these kinds of transfers is that there is, inevitably, also "intellectual, social, and institutional reconfiguration." 25 Particularly in the case of the Russian industry, these other technologies, primarily brought in by major Western studios like Sony, are, in some cases, as important as the programs that were imported. Specifically, these technologies helped the newly formed Russian channels and production companies to understand transnational television standards and produce compelling programming.

Seen in this way, Rosenthal's documentary depicts a building up of human capital and the transfer of knowledge rather than cultural imperialism or American cultural chauvinism. Not all television industries are at equal points in their development, and at times while a genre like the sitcom may be popular and therefore marketable in a country like Russia, it takes time and training to develop the human capital to write, act in, and otherwise generally execute a program in a genre. While Rosenthal's humor and characterization of his Russian hosts at times annoy cultural commentators, the truth is that Rosenthal's observations about the Russian's inability to understand what was at the root of the comedy in Everybody Loves Raymond are justified. Through the concerted on-the-ground efforts of Sony's cadre of consultants, Russian producers learned how to make a successful sitcom. It should be no surprise that the most consistently successful producer of sitcoms in Russia today is the production company Good Story Media, whose first major project was the adaptation of Rosenthal's series.

In the 2000s, sitcoms became the anchor programming of two major entertainment-only television networks in Russia-STS and TNT. The early sitcoms on both networks were produced with help from Sony and, to a lesser extent, other major Hollywood studios like Disney. The success of The Nanny and Married with Children was a boom in adapted sitcoms. By 2007, many personnel who had worked on series like The Nanny and the short-lived adaptation of Home Improvement were brought together by STS' in-house production company Kinokonstanta to create an original Russian sitcom. The sitcom Papiny Dochki (Daddy's Girls) became Russia's first genuinely popular Russian-created sitcom. From there, the market for homegrown sitcoms expanded and eventually surpassed the market for adapted programs in the genre. Two companies became the principal producers of sitcoms by the beginning of the 2010s: Good Story Media and Yellow, Black and White. Both production companies were founded by people who had worked first on Sony-led programs and then on Papiny Dochki.

While the Russian industry still has much to do to truly become a major contributor to the global television economy, it is clearly vying for a role in the market, and sitcoms from Yellow, Black and White and Good Story Media are playing a role. ${ }^{26}$ One of the breakout Russian sitcoms of the 2010s, a series called Kukhnia (The Kitchen), was sold as a format to CBS in 2013. ${ }^{27}$ While CBS has thus far not decided to create an American version of the program, the Russian producers retained the rights to the series in the former Soviet Republics and have so far created versions of the program in Estonia, Greece, and Georgia. CBS licensed the format for a brief, unsuccessful version in Portugal. More recently, Good Story Media signed an agreement with the FOX television channel. A version of its program, Ch.O.P, about the employees of an underfunded private security company will be adapted for American television by Saturday Night Live veteran Steve Koren. ${ }^{28}$ While these series do not represent an overall shift in the dynamics of the global media marketplace, they do 
suggest that the technology transfers Sony brought to Russia along with the shifting dynamics of the market for global formats in the streaming era have positioned Russian sitcom producers as a potential source for formats.

Exporting Raymond presents a case study of a larger process that was at work in Russia from the mid-2000s to the mid-2010s. What is visible in the documentary is a small piece of a much larger process of transferring cultural technologies from Hollywood to Moscow. Before this transfer, Russian sitcoms would have been unviable because, lacking an understanding of the genre, Russian producers would have struggled to create a product that was appealing to Russian audiences. Today sitcoms make up a significant part of the schedules at two of the six major Russian television networks. The flourishing of a genre in such a short period is a testament not only to the clever Russians who appropriated the conventions of the genre but also to the successful transfer of production technologies from Hollywood to Moscow. This process, which is visible in the documentary, has allowed Russians to transition from consumers of global sitcom formats to producing their own series for domestic consumption and finally to producing a few formats that might be viable in the global media market. Should Russia succeed eventually as an exporter of sitcom formats, it will owe much to the technology transfers that Sony initiated and sustained through their long-term engagement in the Russian marketplace.

${ }^{1}$ Jeffrey Brassard is researcher in Residence at St. Joseph's College, University of Alberta. He is the author of articles in the Journal of Popular Film and Television, Palabra Clave, The Journal of Historical Fiction, and VIEW: Journal of European Television History and Culture.

${ }^{2}$ Aniko Imre, TV Socialism (Durham, NC: Duke University Press, 2016).

${ }^{3}$ David Edelstein, "'Exporting Raymond' and 'Cave of Forgotten Dreams," New York Magazine, April 25, 2011, http://nymag.com/movies/reviews/exporting-ray mond-edelstein-review-2011-5/.

${ }^{4}$ Scott Tobias, "In Russia, Loving 'Raymond' Takes Serious Work," NPR.org, April 28, 2011, https://www.npr.org/2011/04/28/135709209/in-russia-loving-raymondtakes-serious-work.

${ }^{5}$ Julia Petuhova, "The Globalization of Encoded Authorship: Copycat Programming in Post-Soviet Era Russia," Film Matters 6 (1, March 1, 2015): 28, https://doi. org/10.1386/fm.6.1.26_1.

${ }^{6}$ Petuhova, "The Globalization of Encoded Authorship," 28.

${ }^{7}$ Katarzyna Marciniak, "Post-socialist Hybrids," European Journal of Cultural Studies 12 (2, May 1, 2009): 173, https://doi.org/10.1177/1367549409102424.

${ }^{8}$ Joseph D. Straubhaar, "Beyond Media Imperialism: Asymmetrical Interdependence and Cultural Proximity," Critical Studies in Mass Communication 8 (1, March 1, 1991): 39-59.

${ }^{9}$ Brett Mills, Television Sitcom (London: BFI, 2005).

${ }^{10}$ Kristin Roth-Ey, Moscow Prime Time: How the Soviet Union Built the Media Empire That Lost the Cultural Cold War (Ithaca, NY: Cornell University Press, 2011).

${ }^{11}$ Elena Prokhorova, "Can the Meeting Place Be Changed? Crime and Identity Discourse in Russian Television Series of the 1990s," Slavic Review 62 (3, autumn 2003): 516. 
12 Jennifer Ryan Tishler, "Menty and the Petersburg Myth: TV Cops in Russia's 'Crime Capital'," Journal of Criminal Justice and Popular Culture 10 (2, 2003): 127-41.

${ }^{13}$ Dana Heller, "Russian 'Sitkom' Adaptation: The Pushkin Principle," Journal of Popular Film and Television 31 (2, 2003): 62.

${ }^{14}$ Interview with Simon Tucker, interview by Author, July 31, 2014.

${ }^{15}$ Interview with international format consultant, interview by Author, July 10, 2014.

${ }^{16}$ Vladimir Nesterov, "Russia Is Running out of TV Shows," Russia Beyond The Headlines, December 24, 2012, http://rbth.ru/articles/2012/12/24/russia_is_ running_out_of_tv_shows_21403.html.

${ }^{17}$ Interview with Marc Lorber, interview by Author, June 30, 2014.

${ }^{18}$ Interview with international format consultant.

${ }^{19}$ Russian Creative Director, Interview with Russian Creative Director, interview by Author, August 11, 2014.

${ }^{20}$ Interview with the VP of International Development and Programming at a US Studio, interview by Author, July 17, 2014.

${ }^{21}$ Vladimir Kozlov, "Russian 'Everybody Loves Raymond' Becomes Longest-Running Adaptation of TV Series," The Hollywood Reporter, October 11, 2017, https://www. hollywoodreporter.com/news /russian-everybody-loves-raymond-becomeslongest-running-adaptation-tv-series-1047644.

${ }^{22}$ Michael Keane, Anthony Y. H. Fung, and Albert Moran, New Television, Globalisation, and the East Asian Cultural Imagination (Hong Kong: Hong Kong University Press, 2007), 88.

${ }^{23}$ Keane et al., New Television, Globalisation, and the East Asian Cultural Imagination, 88-89.

${ }^{24}$ Keane et al., New Television, Globalisation, and the East Asian Cultural Imagination, 89.

${ }^{25}$ Keane et al., New Television, Globalisation, and the East Asian Cultural Imagination, 89.

${ }^{26}$ Jeffrey Brassard, "Russian Sitcoms: From Post-Soviet Copycats to Aspiring Global Players," Palabra Clave 20 (3, June 8, 2017), http://palabraclave.unisabana.edu.co/ index.php/palabraclave/article/view/7239.

${ }^{27}$ Vladimir Kozlov, "CBS Studios International Acquires Rights to Russian Sitcom," The Hollywood Reporter, November 26, 2013, https://www.hollywoodreporter.com/ news/cbs-studios-international-acquires-rights-660071.

${ }^{28}$ Vladimir Kozlov, "Fox Set to Adapt Russian TV Series 'Building Security," The Hollywood Reporter, November 7, 2019, https://www.hollywoodreporter.com/ news/fox-set-adapt-russian-comedy-series-building-security-1253388.

\section{Bibliography}

Brassard, Jeffrey. "Russian Sitcoms: From Post-Soviet Copycats to Aspiring Global Players." Palabra Clave 20, no. 3 (June 8, 2017). http://palabraclave.unisabana.edu.co/index. php/palabraclave/article/view/7239. 
Edelstein, David. "'Exporting Raymond' and 'Cave of Forgotten Dreams'." Magazine. New York Magazine, April 25, 2011. http://nymag.com/movies/reviews/exporting-raymondedelstein-review-2011-5/.

Heller, Dana. "Russian 'Sitkom' Adaptation: The Pushkin Principle." Journal of Popular Film and Television 31, no. 2 (2003): 60-72.

Imre, Aniko. TV Socialism. Durham, NC: Duke University Press, 2016.

Interview with international format consultant. Interview by Author, July 10, 2014.

Interview with Marc Lorber. Interview by Author, June 30, 2014.

Interview with Simon Tucker. Interview by Author, July 31, 2014.

Interview with the VP of International Development and Programming at a US Studio. Interview by Author, July 17, 2014.

Keane, Michael, Anthony Y. H. Fung, and Albert Moran. New Television, Globalisation, and the East Asian Cultural Imagination. Hong Kong: Hong Kong University Press, 2007.

Kozlov, Vladimir. "CBS Studios International Acquires Rights to Russian Sitcom." The Hollywood Reporter, November 26, 2013. https://www.hollywoodreporter.com/ news /cbs-studios-international-acquires-rights-660071.

Kozlov, Vladimir. "Fox Set to Adapt Russian TV Series 'Building Security'." The Hollywood Reporter, November 7, 2019. https://www.hollywoodreporter.com/news/fox-setadapt-russian-comedy-series-building-security-1253388.

Kozlov, Vladimir. "Russian 'Everybody Loves Raymond' Becomes Longest-Running Adaptation of TV Series." The Hollywood Reporter, October 11, 2017. https://www.hollywoodre porter.com/news/russian-everybody-loves-raymond-becomes-longest-runningadaptation-tv-series-1047644.

Marciniak, Katarzyna. "Post-Socialist Hybrids." European Journal of Cultural Studies 12, no. 2 (May 1, 2009): 173-90. https://doi.org/10.1177/1367549409102424.

Mills, Brett. Television Sitcom. London: BFI, 2005.

Nesterov, Vladimir. "Russia Is Running out of TV Shows." Russia Beyond The Headlines, December 24, 2012. http://rbth.ru/articles/2012/12/24/russia_is_running_out_ of_tv_shows_21403.html.

Petuhova, Julia. "The Globalization of Encoded Authorship: Copycat Programming in Post-Soviet Era Russia." Film Matters 6, no. 1 (March 1, 2015): 26-31. https://doi. org/10.1386/fm.6.1.26_1.

Prokhorova, Elena. "Can the Meeting Place Be Changed? Crime and Identity Discourse in Russian Television Series of the 1990s." Slavic Review 62, no. 3 (autumn 2003): 512-24.

Roth-Ey, Kristin. Moscow Prime Time: How the Soviet Union Built the Media Empire That Lost the Cultural Cold War. Ithaca, NY: Cornell University Press, 2011.

Russian Creative Director. Interview With Russian Creative Director. Interview by Author, August 11, 2014. 
Straubhaar, Joseph D. "Beyond Media Imperialism: Asymmetrical Interdependence and Cultural Proximity." Critical Studies in Mass Communication 8, no. 1 (March 1, 1991): 39-59.

Tishler, Jennifer Ryan. "Menty and the Petersburg Myth: TV Cops in Russia's 'Crime Capital'." Journal of Criminal Justice and Popular Culture 10, no. 2 (2003): 127-41.

Tobias, Scott. "In Russia, Loving 'Raymond' Takes Serious Work." NPR.org, April 28, 2011. https://www.npr.org/2011/04/28/135709209/in-russia-loving-raymond-takesserious-work. 
